\title{
Cervical Insemination with Frozen Thawed Semen in Goats at Different Breeding Age
}

\author{
Koray TEKİN* \\ Ankara University, Veterinary Medicine Faculty, Reproduction and Artificial Insemination Department, 06110, Ankara, Turkey
}

\begin{abstract}
Artificial insemination (AI) in goat is currently limited by the poor fertility obtained following the cervical insemination with frozen-thawed semen. The objective of the present study was to determine the efficiency of frozen semen use in two different breeding ages at Saanen goats. The effects of synchronization and fertility rates were also examined. Ninety-eight (98) Saanen goats were divided into two groups: Group-1 $=49$ (7-months-old) and Group-2 = 49 (19-month- old) does. Estrus was synchronized by impregnated intravaginal sponges ( $30 \mathrm{mg}$; fluogestone acetate, FGA), and i.m. administration of $50 \mu \mathrm{g}$ of cloprostenol (PGF2 $\alpha$ ) and pregnant mare serum gonadotropin (PMSG, $500 \mathrm{IU}$ ), at $48 \mathrm{~h}$ before sponge removal. Cervical fixed time AI was carried out with frozen semen $43 \mathrm{~h}$ after removal of the sponges during the breeding season. Estrus was detected by teaser buck. The occurrence of estrus in Group-1 and Group-2 were 71.4\%, 63.3\%, respectively ( $p>0.05)$. Sixty-six (66) goats were inseminated with frozen-thawed semen. The pregnancy rate was determined by abdominal scanning. Pregnancy rates were (Group-1: 31.4\%, Group-2: 32.3\%) not differed significantly between age groups ( $>>0.05$ ). Besides, higher lambing rates were obtained in Group-1 (145.5\%) than in Group-2 $(90.0 \%)$ due to increased prolificacy and reduced embryonic failure. In conclusion, Saanen goats in younger ages, starting from the 7 months old age could be included in the breeding programs and could provide several benefits such as higher percentages of synchronization success and prolificacy.
\end{abstract}

Keywords: Artificial Insemination, breeding age, fertility, frozen semen, pregnancy

\section{Farklı Üreme Yaşındaki Keçilerde Dondurulmuş Sperma ile Servikal Tohumlama}

\section{ÖZ}

Keçide dondurulmuş sperma ile servikal suni tohumlama (ST) uygulaması düşük gebelik oranları nedeniyle halen sınırlıdır. Bu çalışmanın amacı iki farklı üreme yaşındaki Saanen keçilerinde donmuş sperma kullanımının etkinliğini belirlemekti. Senkronizasyon ve gebelik oranlarının etkileri de incelenmiştir. Doksan sekiz (98) dişi Saanen keçisi iki gruba ayrıldı: Grup-1 = 49 (7 aylık) ve Grup-2 = 49 (19 aylık) keçi. Östrus 11 gün süresince intravajinal sünger (30 mg; fluogestone acetate, FGA) ve süngerin ç1karılmasindan 48 saat önce 50 ug kloprostenol (PGF2a) ve gebe kısrak serum gonadotropini (PMSG, 500 IU) ile senkronize edildi. Sabit zamanl servikal tohumlama dondurulmuş sperma ile üreme mevsiminde süngerlerinin çıarılmasından 43-45 saat sonra gerçekleştirildi. Östrus arama tekesi ile tespit edildi. Grup 1 ve Grup 2'de östrus görülme oranları sırasıyla \%71.4, $\% 63.3$ olarak tespit edildi ( $\mathrm{p}>0.05$ ). Altmışaltı (66) keçi dondurulmuş-çözdürülmüşs spermayla tohumlandı. Gebelik abdominal ultrasonografi ile belirlendi. Gebelik oranlanı (Grup-1: \%31.4, Grup-2: \%32.3) yaş gruplanı arasında anlamlı bir farklılık göstermedi $(\mathrm{p}>0.05)$. Ayrıca, artan çoklu doğum ve azalan embriyonik kayıplar sayesinde Grup-1'de (\%145.5), Grup-2'ye (\%90.0) göre daha yüksek oranda yavru elde edilmiştir. Sonuç olarak, Saanen keçileri, 7 aylık yaştan itibaren suni tohumlama programlarına alınabilir ve yüksek senkronizasyon başarısı ve yavru verimine gibi birçok fayda sağlayabilir.

Anahtar Kelimeler: Dondurulmuş sperma, fertilite, gebelik, üreme yaşı, suni tohumlama

To cite this article: Tekin K. Cervical Insemination with Frozen Thawed Semen in Goats at Different Breeding Age. Kocatepe Vet J. (2019) 12(3):357-362

Submission: 10.08.2019 Accepted: 28.08.2019 Published Online: 29.08.2019

ORCID ID; KT: 0000-0002-3862-2337

*Corresponding author e-mail: tekin.koray@hotmail.com 


\section{INTRODUCTION}

Goats play a crucial role due to their high tolerance to heat stress and harsh conditions for many rural communities. In contrast to other ruminants, they are able to convert limited forages and crops into meat, skins and milk easily. The growing demand for goat milk, cheese, yogurt and ice cream triggers the foundation of a new industry, pioneering of novel marketing methods and improving research. However, recent developments in assisted reproductive technology such as artificial insemination (AI) in the small ruminant industry cannot provide adequate success for breeders. Despite the various methods including surgical or non-surgical inseminations that are being used in both primiparous and multiparous goats, success rates are limited by the poor fertility (Leboeuf et al. 1998, Cognie et al. 2003, Purdy et al. 2009, Kulaksiz et al. 2012).

The success of AI contains various stages such as age, health, semen collection and storage, estrus detection and mainly the insemination technique (Leboeuf et al. 2000, Arrebola et al. 2012, Yeni and Gundogan 2018). Associated with our study, insemination techniques are classified into two types, surgical and non-surgical (Althouse 2007). Cervical insemination is noninvasive and a low-cost technique that can be counted in non-surgical part. However, the complexity of the cervical anatomy of small ruminants is the primer limit of success rates in this method. It is performed by transferring the semen into the cervix with the aid of an adequate catheter and speculum. An adequate catheter and selection of does affect the advance of the catheter in the cervical rings and thereby the depth of semen deposition into the cervix, which leads to higher pregnancy rates (Leethongdee and Ponglowhapan 2014). For this purpose, the breeding age of does can be related to the success rate of this AI technique. In line with this hypothesis, in anatomical research, the length of the cervix showed a variance regarding the age and previous pregnancy status in ewes and does (Hyacinth et al. 2016). In another study in goat, it has been stated that multiparous does have longer cervix length than primiparous ones, that favors deeper penetration and it could be associated with elevated pregnancy rates due to the depth of semen deposition in the genital tract (Intrakamhaeng et al. 2011). Salomon and Maxwell (1995) has reviewed various studies in ewes and concluded that lambing rates increased with the depth of insemination. However, to the best of our knowledge, the relationship between cervical AI success and age has not been investigated in Saanen goats. Therefore, we aimed to determine this relationship by performing a cervical AI by using frozen-thawed buck semen in Saanen goats at different breeding ages.

\section{MATERIAL and METHODS}

\section{Animal Maintenance and Selection}

This study was conducted at the private farm in

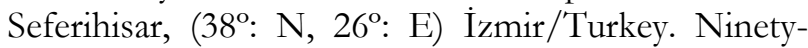
nine Saanen goats, at 7 or 19 months of age, were selected by their final evaluation score. The animals were maintained under the constant nutritional regime, dehydrated alfalfa; mineral salts and water were provided adlibitum.

All animals were selected where the following criteria meet: The one with at least 2.75 body condition score, average body weight between $50-55 \mathrm{~kg}$, showed at least 3 visible regular (21 days) estrus cycle and confirmed by ultrasound examination of the reproductive tract before the hormonal treatment. This study was conducted according to ethical laws and regulation of Ankara University Animal Experiments Local Ethics Committee.

\section{Estrus Synchronization}

Forty-nine primiparous and forty-nine nulliparous Saanen goats were synchronized according to Lebouef et al. (2007), during the breeding season. All animals were treated with an intra-vaginal sponge (30 $\mathrm{mg}$ fluogestone acetate, FGA) for 11 days, intramuscular injection of $500 \mathrm{IU}$ pregnant mare serum gonadotropin (PMSG), and $50 \mu \mathrm{g}$ prostaglandin F2alpha (d-cloprostenol, Juramate) were administered 48 hours before the sponge removal.

\section{Estrus Detection}

Estrus was detected with a teaser buck $24 \mathrm{~h}$ after the sponge removal. Behavioral and physiological changes were examined according to following criteria; the females that does not have standing heat and one more estrus sign (tail wagging, cervical mucus, urination) have been discarded from the insemination program.

\section{Semen assessment and AI}

Semen samples were imported commercially from Capgenes, France. A total of 66 frozen semen straws from three different bucks were used. Frozen semen samples were thawed at $37^{\circ} \mathrm{C}$ for $30 \mathrm{sec}$, gently dried, placed into insemination gun and kept not more than 5 min before use. All the does were restrained by two technicians gently and perianal disinfection is done before the insemination. The hindquarters of does were raised over a rail, and semen was deposited as deeply as possible into the cervix through a speculum fixed with a light source. Timed artificial inseminations were performed at 43-45 hours from sponge removal.

\section{Pregnancy detection}

Does were positioned in dorsal recumbence and monitored abdominal ultrasound with using a 7.5 
$\mathrm{MHz}$ linear probe (Esaote, Lab-One, Italy) 30 days after insemination and kidding rates were recorded.

\section{Statistical analysis}

Chi-square analysis was performed to test the significance of the difference between pregnancy status and date of birth. In all analysis $\mathrm{p}<0.05$ was considered as statistically significant. All statistical analysis was performed using SPSS for Windows 14.1 .

\section{RESULTS}

The success rate of synchronization was recorded as $71.4 \%$ in Group 1, 63.3\% in Group 2 and there was no significant difference between the age groups
( $p>0.05$ ). Likewise, the overall pregnancy rate was found $31.8 \%$ and similar pregnancy rates were obtained in Group 1 and Group 2 as 31.4\%, and $32.3 \%$ respectively $(\mathrm{p}>0.05)$ (Table 1$)$.

A total of 25 offspring were obtained from 21 pregnant does, six twin pregnancies in Group 1, one triple pregnancy in Group 2, four early embryonic losses (one in Group 1 and three in Group 2) and one false pregnancy in Group 2 were detected owing to the use of ultrasonography. Overall lambing rate was $119.0 \%$. Although there was no statistically significant difference between the groups lambing rate was higher in Group $1(145.5 \%)$ than Group 2 (90.0\%) (Table 2).

Table 1. Synchronization success and pregnancy rates of age groups

\begin{tabular}{|c|c|c|c|c|c|c|c|}
\hline & & \multicolumn{2}{|c|}{ Synchronization } & \multicolumn{4}{|c|}{ Pregnancy } \\
\hline & & $\mathbf{n}$ & $\begin{array}{c}\text { Does in } \\
\text { Estrus (\%) }\end{array}$ & $\mathrm{n}$ & $\begin{array}{l}\text { Pregnant } \\
\text { does }(\%)\end{array}$ & $\mathrm{n}$ & $\begin{array}{c}\text { Non-Pregnant } \\
\text { does }(\%)\end{array}$ \\
\hline \multirow{2}{*}{ Age } & Group 1 & 35 & 71.4 & 11 & 31.4 & 24 & 68.6 \\
\hline & Group 2 & 31 & 63.3 & 10 & 32.3 & 21 & 67.7 \\
\hline
\end{tabular}

Table 2. Various reproductive parameters of age groups

\begin{tabular}{ccccc}
\hline Reproductive parameters & $\mathbf{n}$ & Group 1 (\%) & $\mathbf{n}$ & Group 2 (\%) \\
\hline Twin rate & 6 & 54.6 & 0 & - \\
Triplet rate & 0 & - & 1 & 10.0 \\
Kids/Inseminated does & $16 / 35$ & 45.7 & $9-31$ & 29.0 \\
Kids/Pregnant does & $16 / 11$ & 145.5 & $9-10$ & 90.0 \\
Early embryonic loss & 1 & 2.9 & 3 & 9.7 \\
False pregnancy & 0 & - & 1 & 10.0 \\
\hline
\end{tabular}

\section{DISCUSSION}

In order to obtain the maximum reproductive efficiency, does should be bred as soon as they reach their sexual maturity. Thus, it is essential to establish a breeding program considering the specific time of the birth that the offspring could reach the puberty at the beginning of the breeding season. The success of the synchronization followed by the pregnancy outcome depends on many factors including the reproductive history of the females. Nulliparity, primiparity and multiparity, hence, the age of the animal could affect the reproductive outcome.
In the present study, the effect of age on fertility was investigated. Although the pregnancy rates were similar between the nulliparous and primiparous goats, the efficiency of synchronization was numerically higher in younger animals $(p>0.05)$. Variation of the response to the synchronization due to the difference in the ages of does has been documented by several researchers (Sanwal et al. 1983, Mellado et al. 2000, Romano et al. 2000, Whitley and Jackson 2004). Although some protocols have led to higher superovulation rates in younger females (Sanwal et al., 1983), other methods such as teasing have not been effective in young, postpubertal animals (Mellado et al. 2000). In a study 
conducted by Romano et al. (2000), the fertility of the multiparous does were found highest followed by the nulliparous females, while the lowest was observed in primiparous does, on the contrary to prolificacy rates.

Another factor that plays a role in the success of synchronization is the type of hormonal product used. Motlomelo et al. (2002) compared the fertility of the ninety does synchronized with controlled internal drug (progesterone)-releasing device (CIDR), Methyl acetoxy progesterone (MPA) or FGA for 16 days and found that the estrus rates were highest in CIDR group $(100 \%)$ and lowest in MAP group $(93 \%)$, however, the lowest conception rates were obtained in CIDR group (46.7\%) while it was highest in FGA group $(60 \%)$. Despite the variables such as the duration of progesterone treatment, breed, age and the semen processing, in the present study, $67.3 \%$ of the does FGA treated does have shown visible estrus signs, ranging from $71.4 \%$ to $63.3 \%$ regarding the age groups of the animals. Thus, it can be concluded that FGA is a more reliable choice of progesterone derivate in younger does.

As studied by many researchers, the fertility of the females is depended on several factors. The breed, the age of the animals (Anel et al. 2005), the specific time of insemination (Karagiannidis et al. 2001, Donovan et al. 2001, 2004, Fernandez Abella et al. 2003,) the performing professional (Anel et al. 2005), the doses of hormonal treatments (Tirpan et al. 2019, Hill et al. 1998), the processing of semen that is being used (Donovan et al. 2001, 2004, Hill et al. 1998, Ehling et al. 2003, Fernandez-Abella et al. 2003) and the method of insemination (Salamon and Maxwell 1995, Moses et al. 1997, Anel et al. 2005, Donovan et al. 2001, 2004, King et al. 2004, Szabados 2006, Perkins et al. 1996, Yamaki et al. 2003). In the present study, cervical inseminations were performed by using frozen-thawed semen and similar pregnancy rates were obtained in Group 1 and Group 2 as $31.4 \%$ and $32.3 \%$ respectively. In comparison with other researches, this rate was acceptable (Karatzas et al. 1997, Donovan et al. 2001, 2004, Stanimir et al. 2016). Donovan et al. (2001) have compared the pregnancy rates of six different breeds of ewes after the cervical insemination with frozen-thawed semen. Surprisingly, the pregnancy rates were varied from $18 \%$ to $77 \%$, and from these results, it was obvious that the bred has a major effect on the pregnancy outcome of the inseminations. In another study, the pregnancy rate was found $44 \%$ when the choice of the method was cervical inseminations (Donovan et al. 2004), although laparoscopic insemination method has yielded $71.6 \%$ (Hill et al. 1998). Despite the higher pregnancy rates obtained with laparoscopic insemination method, it is an invasive and highly expensive method in which many equipment and expert labor need. Furthermore, concerns about animal welfare limit the application of this method.
When the effect of age was focused regarding the success of AI practices, according to the study conducted on 44,448 Churra sheep, the fertility outcome of the intravaginal insemination was decreasing in $1.7 \%$ per year with the ewes being aged and the difference was more visible when the laparoscopic insemination method was performed $(2.0 \%)$ (Anel et al. 2005). Furthermore, they discovered that the fertility rates of vaginal insemination increases until 3.5 years of age, peaks up to 4.5 and begins to decrease after that. In the present study, there was no significant difference between the 7 months old and 19 months old does regarding the pregnancy rates although the lambing rate was found higher in the younger age group.

In the present study, overall lambing rate was 1.19, which was varied from 1.45 to 0.9 regarding the age groups and was higher in younger animals; however, it was lower than the data collection of Andries (2017), in which the rate was found 1.84. Animalrelated factors such as breed, age, body condition score, genetics, and environmental factors including season, weather, stress, nutrition, pasture composition have a great impact on the lambing rate. The change in the litter size with the aging was investigated by using the data from 29,567 Polypay and Suffolk breed ewes and resulted in the information that starting from the 1 year of age, the litter size increases, up to 4-7 years of age followed by a decrease after 7 years of age. Similarly, 15-month-old ewes had +0.21 litter size as compared to 12-month-old ewes (Notter 2000).

Apart from these factors, the difference in the lambing rate might have mainly been caused by two reasons. The enhanced prolificacy rate of younger animals can be linked with the increased hormonal response, considering the same PMSG doses were used for both groups. Besides, in our previous study (Tirpan et al. 2019), higher PMSG doses (400 to 500 IU) have led to the alterations in the timing of ovulation and $500 \mathrm{IU}$ dose shortened the duration of estrus behaviors in Angora goats. In addition, it has been reported that the PMSG doses significantly affects the conception rates (Hill et al. 1998). The survey study of 28,444 Merino ewes, which were inseminated laparoscopically revealed that starting from the dose of $200 \mathrm{IU}(62.4 \%)$ the conception rate increases with peaking at $300 \mathrm{IU}(79.1 \%)$ and decreasing above $375 \mathrm{IU}$ (69.4\%).

Besides from that phenomenon, the embryonic mortality rate was higher in older does $(25.0 \%)$ than in younger ones $(5.8 \%)$. Embryonic failures may lead to critical economic loss to the breeders of seasonally bred reproducing animals such as sheep and goats since when it is detected, it is often far beyond the point to rebreed the females (Diskin and Morris 2008). Various factors such as breed, genetics, 
nutrition, ovulation rate and previous pregnancy history could affect the survival rate of the embryos (Bolet 1986). Although similar embryonic mortality rates were observed among different species like pigs, sheep and goats, different mechanisms are accounted for these losses. On contrary to sheep, in pigs, the effect of the breed has more importance than the ovulation rate and the main reason behind the embryonic loss in goats is the failure of corpus luteum (Wentzel 1982) since as distinctive from the sheep; gestation is dependent on corpus luteum in goats. Samir et al. (2016), investigated the effect of parous and breed on the embryonic and fetal failure in Zaraibi, Damascus and crossed breeds and obtained that the overall incidence was $41.3 \%$. According to the results, significant differences were obtained regarding the age and the breed. Similar to the present results, the incidences of embryonal and fetal failures were encountered more frequent in does older than 3 years of age (44\%) compared to the younger ones $(38 \%)(p<0.05)$. Although when the effect of the breed was also taken into account, this outcome was reversed in Zaraiebi breed as the higher embryonic mortality rate was obtained in younger animals. Furthermore, contrarily with the present study, the incidence has found higher in nulliparous does $(42 \%)$ than parous ones $(40 \%)$ p $(<0.05)$. However, in Damascus and Crossed breeds, nulliparous does have shown the reversed results, with lower incidences $(\mathrm{p}<00.5)$. In sheep, a substantial-high 292 percentage of incidence in parous merino and Pleven blackhead sheep were observed without any significant difference in the IIe de France breed $(p<0.05)$ (Yotov 2012). It was concluded that previous pregnancy status of the animals had a different effect on the embryo loss within each breed indicating the importance to build up strategies to optimize the fertility of small ruminants in each breed. The increase of the incidence of embryonic failure in parous females could be due to the possible microbial contamination of the uterus during the previous pregnancies that could lead to alterations in the environment of the uterus and/or could cause cytolytic effect on the embryo as well as the epithelial changes of the uterus (Yotov 2012, Vanroose et al. 2000).

In conclusion, Saanen does in younger ages, starting from the 7 months old age could be included in the breeding programs and could provide several benefits such as higher percentages of synchronization success and prolificacy in addition to the decreased frequency of embryonic failures; however, it is necessary to consider the variations of the reproductive parameters among different breeds. Besides, cervical insemination technique could easily be applied on a larger scale farm, and it could be considered as a method that simplifies the use of frozen buck semen in Turkey.

\section{REFERENCES}

Althouse G. Artificial Insemination In: Comparative reproductive biology, Ed; Schatten $\mathrm{H}$, Constantinescu GM, Ames IO, Blackwell. 2007; pp. 159-170.

Andries KM. Using Performance Ratios and EBVs for Selection in Meat Goats. In: Agricultural Research and Extension Program Langston University, Proceedings of the $32^{\text {nd }}$ Annual Goat Field Day, April 29, Oklahoma, USA. 2017.

Anel LM, Kaabi B, Abroug M, Alvarez E, Anel JC, Boixo LF. Factors influencing the success of vaginal and laparoscopic artificial insemination in Churra ewes: a field assay. Theriogenology. 2005; 63: 1235-1247.

Arrebola FA, Pardo B, Sánchez M, López MD, Pérez-Marín CC. Factors influencing the success of an artificial insemination program in Florida goats. Spanish Journal of Agricultural Research. 2012; 10(2): 338-344.

Bolet G. Timing and extent of embryonic mortality in pigs, sheep and goats: Genetic Variability. In: Embryonic mortality in farm animals, Ed; Sreenan JM, Diskin M, Springer Dordrecht. 1986; pp. 12-43.

Cognie Y, Baril G, Poulin N, Mermillod P. Current status of embryo technologies in sheep and goats. Theriogenology. 2003; 59: 171-188.

Diskin MG, Morris DG. Embryonic and early foetal losses in cattle and other ruminants. Reprod Domest Anim. 2008; 43(2): 260-267.

Donovan A, Hanrahan JP, Kummen E, Duffy P, Boland MP. Fertility of the ewe following cervical insemination with fresh or frozen-thawed semen at natural or synchronised oestrus. Animal Reproduction Science. 2004; 84: 359-368.

Donovan A, Hanrahan JP, Lally T, Boland MP, Byrne GP, Duffy P, O'Neill DJ. AI for sheep using frozen-thawed semen. ARMIS 4047 Project report under the Research Stimulus Fund; OPARDF measure 5b. 2001.

Ehling C, Wirth P, Schindler L, Hadeler KG, Döpke HH, Lemme $\mathbf{E}$, Niemann $\mathbf{H}$. Laparoscopical intrauterine insemination with different doses of fresh conserved and frozen-thawed semen for the production of ovine zygotes. Theriogenology. 2003; 60: 777-787.

Fernandez Abella D, Preve MO, Villegas N. Insemination time and diluting rate of cooled and chilled ram semen affects fertility. Theriogenology. 2003; 60: 21-26.

Hill JR, Thompson JA, Perkins NR. Factors affecting pregnancy rates following laparoscopic insemination of 28447 Merino ewes under commercial conditions: a survey. Theriogenology. 1998; 49: 697-709.

Hyacinth AA, Terzungwe A, Daniel OL, Oluwabamise NJ. Biometrical Study of the Genitalia of Kano Brown Goats and Yankasa Sheep. IJAVMS. 2016; 10(1): 3-8.

Intrakamhaeng M, Kongbuntad W, Wangkahart E, Khalid $\mathbf{M}$, Leethongdee $\mathbf{S}$. The anatomy of cervix and the cervical penetrability during oestrus in the Thai goat. Reproduction in Domestic Animals. 2011; 46: 113.

Karagiannidis A, Varsakeli S, Karatzas G, Brozos C. Effect of time of artificial insemination on fertility of progestegen and PMSG treated indigenous Greek ewes during nonbreeding season. Small Ruminant Research. 2001; 39(1): 67-71.

Karatzas G, Karagiannidis A, Varsakeli S, Brikas P. Fertility of fresh and frozen-thawed goat semen during the nonbreeding season. Theriogenology. 1997; 48(6): 10491059 . 
King ME, McKelvey WAC, Dingwall WS, Matthews KP, Gebbie FE, Mylne MJA, Robinson JJ. Lambing rates and litter sizes following intrauterine or cervical insemination of frozen-thawed semen with or without oxytocin administration. Theriogenology. 2004; 62: 12361244.

Kukovics S, Gyökér E, Németh T, Gergátz E. Artificial insemination of sheep-possibilities realities and techniques at the farm level. In: Artificial insemination in farm animals. Ed; Manafi M, InTech Crotia. 2011.

Kulaksiz R, Daskin A. Reproductive performance of primiparous and multiparous Saanen goats after laparoscopic intrauterine insemination: a field study. Turkish Journal of Veterinary and Animal Sciences. 2012; 36(2): 201-204.

Leboeuf B, Delgadillo JA, Manfredi E, Piacère A, Clément V, Martin P, De Cremoux R. Management of goat reproduction and insemination for genetic improvement in France. Reproduction in Domestic Animals. 2008; 43: 379-385.

Leboeuf B, Manfredi E, Boue P, Piacère A, Brice G, Baril G, Terqui M. Artificial insemination of dairy goats in France. Livestock Production Science. 1998; 55(3): 193203.

Leboeuf B, Restall B, Salamon S. Production and storage of goat semen for artificial insemination. Animal Reproduction Science. 2000; 62(1-3): 113-141.

Leethongdee S, Ponglowhapan S. Artificial insemination in goats: an update. Thaj J Vet Med. 2014; 44(1): 73-77.

Mellado M, Olivas R, Ruiz F. Effect of buck stimulus on mature and pre-pubertal norgestomet-treated goats. Small Ruminant Research. 2000; 36(3): 269-274.

Moses D, Martinez AG, Iorio G, Valcarcel A, Ham A, Pessi $\mathbf{H}$, De Las Heras MAA. Large-scale program in laparoscopic intrauterine insemination with frozenthawed semen in Australian Merino sheep in Argentine Patagonia. Theriogeneology. 1997; 48: 651-657.

Motlomelo KC, Greyling JPC, Schwalbach LMJ. Synchronisation of oestrus in goats: the use of different progestagen treatments. Small Ruminant Research. 2002; 45(1): 45-49.

Notter DR. Effects of ewe age and season of lambing on prolificacy in US Targhee Suffolk and Polypay sheep. Small Ruminant Research. 2000; 38(1): 1-7.

Perkins NR, Hill JR, Pedrana RG. Laparoscopic insemination of frozen-thawed semen into one or both uterine horns without regard to ovulation site in synchronised Merino ewes. Theriogenology. 1996; 46: 541-545.

Purdy PH, Blackburn HD, Larson B, Stobart R. Investigation of a Novel Non-Surgical Method of Artificial Insemination for Sheep. Publications from USDA-ARS / UNL Faculty.1395. 2009: http://digitalcommons.unl.edu/usdaarsfacpub/1395

Romano JE, Crabo BG, Christians CJ. Effect of sterile service on estrus duration fertility and prolificacy in artificially inseminated dairy goats. Theriogenology. 2000; 53(6): 1345-1353.

Salamon S, Maxwell WM. Frozen storage of ram semen II. Causes of low fertility after cervical insemination and methods of improvement. Animal Reproduction Science. 1995; 38(1-2): 1-36.

Samir H. Karen A. Ashmawy T. Abo-Ahmed M. El-Sayed M. Watanabe G. Monitoring of Embryonic/Fetal Losses in Different Breeds of Goats using Real Time B- Mode Ultrasonography. Theriogenology. 2016; 85(2): 207-215.

Sanwal PC, Pande JK, Varshney VP, Mogha IV. Gonadotrophin-induced ovulation in melengestrol acetate treated female goat. Indian Journal of Physiology And Pharmacology. 1983; 27(1): 57-60.

Szabados T. A cervikouterinális inszeminálás eredményességének vizsgálata juhászatokban /Study of effectiveness in cervico-uterinal insemination of ewes. $\mathrm{PhD}$ thesis, University of Western Hungary Faculty of Agriculture and Food Sciences, Mosonmagyaróvár Hungary, 2006.

Tirpan MB, Tekin K, Cil B, Alemdar H, Inanc ME, Olgac KT, Stelletta C, Daskin A. The effects of different PMSG doses on estrus behavior and pregnancy rate in Angora goats. Animal. 2019; 13(3): 564-569.

Vanroose G, de Kruif A, Van Soom A. Embryonic mortality and embryo-pathogen interactions. Animal Reproduction Science. 2000; 60: 131-143.

Wentzel D. Non-infectious abortion in Angora goats. $3^{\text {rd }}$ Intern conference on goat production and disease. Tuscon, 10 15 Jan. 1982; pp: 155-161. Dairy goat Journal publishing Co. Scottsdale USA. 1982; pp: 155-161.

Whitley NC, Jackson DJ. An update on estrus synchronization in goats: A minor species Journal of Animal Science. 2004; 82(13): E270-276.

Yamaki K, Morisawa M, Ribadulla A, Kojima J. Sheep semen characteristics and artificial insemination by laparoscopy. Tohoku Journal of Agricultural Research. 2003; 54(1-2): 17-26.

Yeni D, Gündoğan M. Some andrological parameters and biochemical properties in relation to season in rams. Kocatepe Veterinary Journal. 2018; 11(1): 70-85.

Yotov SA. Ultrasound diagnostics of late embryonic and foetal death in three sheep breeds. Journal of Veterinary Advances. 2012; 2(3): 120-125.

Yotov SA, Velislavova DV, Dimova LR. Pregnancy rate in Bulgarian White milk goats with natural and synchronized estrus after artificial insemination by frozen semen during breeding season. Asian Pacific Journal of Reproduction. 2016; 5(2): 144-147. 